\title{
Download
}

$\underline{\text { https://doi.org/10.17721/2308-135 }} \underline{\text { X }} \underline{.2019 .44 .68-80}$

UDC $908+379.85(477+438)$

Liubitseva Olha Olexandrivna, doctor of geographical sciences, professor, Taras Shevchenko National University of Kyiv, Kyiv,

Ukraine

e-mail:

loa13@ukr.net

">

loa13@ukr.net

Voytsekhovsky Kshyshtof, Lublin Landscape Parks Unit, Lublin, Poland, e-mail: wojciechowsk i.krzysztof@lubelskie.pl

">wojciechowski.krzysztof@lubelskie.pl

Zinko Yuriy Volodymyrovych, Ivan Franko National University of Lviv, Lviv, Ukraine, e-mail: zi nkoyuriy@gmail.com

Kochetkova Iryna Valentynivna,Ph.D. in Geography, assistant, Taras Shevchenko National University of Kyiv, Kyiv,

e-mail:

kiv_univ@ukr.net 


\section{CROSS-BORDER COOPERATION IN THE SPHERE OF TOURISM IN Roztocze}

Purpos. Show directions for the development of promising types of tourism with a view to cross-border cooperation in Ukrainian and Polish

Roztocze

Methodology is based on the use of modern methods of searching and processing heterogeneous information, its analysis, synthesis and generalization.

Results. Based on the analysis of recreational tourism resources and potential, directions for the development of cross-border cooperation with the aim of developing small settlements in Roztocze were proposed.

Scientific novelty. Generalized recreational and tourist resources of the Polish and Ukrainian Roztocze, including latent ethno-memorial resources, are disclosed. Identified promising types and forms of tourism activities.

Practical significance. Proposed areas of cross-border cooperation between Ukraine and Poland at the Roztocze, in particular on the development of active recreation and ethno-cultural tourism.

Keywords. Roztocze, recreational and tourist resources and potential, active, ecological, cultural and educational tourism

References: 
1. Liubitseva O. The use of recreational and tourist potential of Roztocze of tourism in Poland and Ukraine / O.Liubitseva, K.Voytsekhovsky, Y. Zinko, I. Kochetkova // Geography at the Taras Shevchenko National University of Kyiv: 85 Years - Achievements and Prospects (GTSNU): Proceedings of the International Scientific and Practical Conference dedicated to the 85th anniversary of the Faculty of Geography of Taras Shevchenko National University of Kyiv (Kyiv, 30-31 March 2018) / head of editorial board Y. B. Oliynyk; KNU named after Taras Shevchenko.

- K.: Print-Service, 2018. - 361 p. - pp. 206-209

2. Nature of Lviv region / Ed. K.I. Gerenchuk. - Lviv: High School. Publishing house at Lviv University, 1972. - $151 \mathrm{p}$.

3. Topornitska M.Y. Territorial organization of ethno-festival tourism in Lviv region: Abstract of the dissertation of PhD geogr. sciences: 11.00.02 / M. Y. Topornitska. - Chernivtsi, 2015. - 19 p.

4. Physical-geographical zoning of the Ukrainian SSR / Ed. V.P. Popov. - Kyiv.: Kyiv University, 1968.- $684 \mathrm{p}$.

5. Krajobrazy Roztocza. Landscapes Roztocze. Photo album. - Lublin, 2017.- 84 s.

6. Mrozowicz K. Analiza popytu turystycznego na przykładzie badań konsumentów produktu turystycznego Roztocza Zachodniego / K. Mrozowicz, P. Halemba , A. Winiarz // Zeszyty Naukowe Uniwersytetu Szczecińskiego. Ekonomiczne Problemy Usług, № 84 Popyt turystyczny: konsumpcja-segmentacja-rynki, 2012. - 79-94

7. Od regionu geograficznego do regionu turystycznego. Lubelszczyzna - implikacje historyczne, teoretyczne, naukowo-badawcze, edukacyjne/R

d. T. Brzezińska-Wójcik, E. Skowronek, A. Świeca.- Lublin.: Wydawnictwo UMCS, 2016.-195 s.

8. Sawicki B. Dziedzictwo kulturowe Środkowego Roztocza jako czynnik rozwoju turystyki / B. Sawicki, S. Golian // Problemy Ekologii Krajobrazu, tom XXVII, 2010. - 345-351. 
9. Szlak Chasydzki. Kraśnik - Fundacja Ochrony Dziedzictwa Żydowskiego. [Електронний pесурс]. - Режим доступу: http://fodz.pl/download/szlak_chasydzki_krasnik_PL.pdf

10. Turystyka na Roztoczu / Andrzej Świeca, Teresa Brzezińska-Wójcik, Ewa Skowronek, Renata Krukowska, Andrzej Tucki, Tadeusz Grabowski, Marta Malska, Yuriy Zinko, Vitalij Brusak, Ihor Pandiak, Oksana Shevchuk // Roztocze: przyroda i człowiek / [Red. naukowa: T. Grabowski, M. Harasimiuk, B. M. Kaszewski, Y. Kravchuk, B. Lorens, Z. Michalczyk, O. Shabliy]. - Zwierzyniec: Roztoczański Park Narodowy, 2015. - 391-427. 